\title{
Potensi Keanekaragaman Flora Sebagai Tumbuhan Obat di Wana Wiyata Widya Karya, Sanggar Indonesia Hijau, Kabupaten Pasuruan
}

\author{
Potency of Flora Diversity as Herbs in Wana Wiyata Widya Karya, Sanggar \\ Indonesia Hijau, Regency of Pasuruan
}

\author{
Nourma Hildasari ${ }^{1}$ dan Ari Hayati ${ }^{1 *}$ \\ ${ }^{1}$ Program Studi Biologi, Fakultas Matematika dan Ilmu Pengetahuan Alam, Universitas Islam Malang, \\ Malang, Indonesia
}

\begin{abstract}
Abstrak
Tumbuhan merupakan komponen keanekaragaman hayati yang menjadikan Indonesia memiliki kekayaan alam terbesar urutan kedua di dunia. Salah satu pemanfaatan fungsi tanaman adalah sebagai tanaman obat. Tumbuhan obat adalah bahan yang berasal dari tumbuhan yang masih sederhana, murni, belum tercampur atau belum diolah, yaitu tumbuhan yang tinggal dipetik dan diracik, kemudian langsung dikonsumsi. Penelitian ini bertujuan untuk mengetahui jenis tumbuhan obat yang terdapat di Wana Wiyata Widya Karya, Sanggar Indonesia Hijau, Kabupaten Pasuruan dan jenis organ tumbuhan obat yang digunakan sebagai obat. Metode yang digunakan adalah penelitian deskriptif melalui metode jelajah dan pengambilan spesies di area penelitian. Hasil inventarisasi menunjukkan bahwa tumbuhan yang berkhasiat sebagai obat berjumlah 55 jenis yang berasal dari 34 famili. Jenis organ tumbuhan yang berkhasiat obat teridentifikasi sebanyak 10 bagian. Presentase organ tumbuhan obat yang paling banyak digunakan untuk keperluan obat adalah daun dengan nilai $47 \%$, buah $27 \%$, biji $7 \%$, rimpang $5 \%$, getah $4 \%$, serta kulit pohon, umbi, bunga, tangkai daun, dan batang masing-masing sebanyak $2 \%$.
\end{abstract}

Kata kunci: Inventarisasi, tanaman obat, organ, Wana Wiyata Widya Karya

\begin{abstract}
Plants as a component of biological diversity has contributed to Indonesia status as second largest contry in the world to have natural resources. One of plant utilization is to be used as medicinal plant. Medicinal plants are ingredients derived from plants that are still simple, pure, not mixed or processed, namely plants that can only be picked and mixed, then consumed immediately. The aim of this research is to inventarize types of medicinal plants in Wana Wiyata Widya Karya Sanggar, Indonesia Hijau in Regency of Pasurauan and to identify plant organs used in medicinal purpose. This research employed descriptive research method through expoloration and species collection in research area. inventarization of medicinal plant listed 55 species from 34 families. Ten types of plant organ were identified to be utilized in medicinal purpose. Leaves was identified as the most widely plant organ used for medicinal purpose with a value of $47 \%$, followed by fruit (27\%) seeds (7\%), rhizomes (5\%), sap (4\%), and each of tree bark, tubers, flowers, petioles and stems (2\%).
\end{abstract}

Keywords : inventaryzation, medicinal plants, plant organs, Wana Wiyata Widya Karya

\footnotetext{
* Corresponding author:

Ari Hayati

Program Studi Biologi, Fakultas Matematika dan Ilmu Pengetahuan Alam, Universitas Islam Malang, Jl. Mayjen Haryono No.193, Dinoyo, Kec. Lowokwaru, Kota Malang, Jawa Timur, Indonesia

Email : ari.hayati@unisma.ac.id
} 


\section{Pendahuluan}

Inventarisasi tumbuhan merupakan suatu kegiatan menghimpun atau mengoleksi suatu jenis-jenis tumbuhan yang terdapat pada suatu daerah. Inventarisasi tumbuhan bertujuan mengumpulkan data suatu kawasan tentang kekayaan jenis suatu tanaman (Tjitrosoepomo, 1998). Identifikasi tumbuhan merupakan salah satu kegiatan dalam proses inventarisasi tumbuhan. Identifikasi tumbuhan didefinisikan sebagai usaha mengungkapkan atau menetapkan identitas suatu tumbuhan. Secara praktis, identifikasi tumbuhan bertujuan untuk menentukan namanya yang benar dari tumbuhan tersebut dan tempatnya yang tepat dalam sistem klasifikasi (Tjitrosoepomo, 1988).

Tumbuhan obat adalah tumbuhan yang memiliki khasiat obat dan digunakan sebagai obat dalam penyembuhan maupun pencegahan penyakit. Pengertian berkhasiat obat adalah mengandung zat aktif yang berfungsi mengobati penyakit tertentu atau jika tidak mengandung zat aktif tertentu tapi mengandung efek resultan/sinergi dari berbagai zat yang berfungsi mengobati (Azwar, 2010; Hariana, 2006). Pengetahuan tentang tumbuhan berkhasiat obat ini sudah lama dimiliki oleh nenek moyang kita dan hingga saat ini telah banyak yang terbukti secara ilmiah. Pemanfaatan tumbuhan obat Indonesia akan terus meningkat karena kuatnya keterkaitan bangsa Indonesia terhadap tradisi memakai jamu (Heyne, 1987).

Sanggar Indonesia Hijau (Si Hijau) merupakan wadah pegiat lingkungan yang berada di Desa Cowek, Kecamatan Purwodadi, Kabupaten Pasuruan, Provinsi Jawa Timur (Gambar 1). Si Hijau berdiri pada tahun 2015 atas inisiatif Bapak Sugiarto sebagai tokoh masyarakat di Desa Cowek. Ruang gerak Si Hijau berada pada ranah pendidikan, pelatihan, dan pemagangan terkait botani. Untuk mendukung kegiatan, Si Hijau mempunyai tempat pembelajaran yang diberi nama Wana Wiyata Widya Karya sebagai tempat untuk mempelajari tentang tanaman, sumber mata air dan juga lingkungan. Si Hijau juga telah menyediakan pendidikan tentang pembibitan tanaman, konservasi tanah, air dan wawasan lingkungan.

Berdasarkan hasil wawancara dengan pengelola Si Hijau, belum pernah dilakukan kegiatan Inventarisasi tanaman berpotensi obat di lokasi tersebut. Penelitian ini bertujuan untuk mengidentifikasi jenis-jenis tumbuhan obat di Wana Wiyata Widya Karya, Sanggar Indonesia Hijau, Kabupaten Pasuruan dan mengetahui bagian organ tumbuhan yang digunakan sebagai obat.

\section{Materi dan Metode \\ Waktu dan Tempat Penelitian}

Penelitian ini dilaksanakan pada bulan Juli sampai September 2020 di Wana Wiyata Widya Karya Sanggar Indonesia Hijau, Dusun Selowinangun RT. 03, Desa Cowek, Kecamatan Purwodadi, Kabupaten Pasuruan, Jawa Timur.

\section{Alat dan Bahan}

Untuk alat dan bahan yang digunakan antara lain : alat tulis untuk mencatat hasil kegiatan, kamera untuk mendokumentasikan kegiatan penelitian, laptop untuk menganalisis dan mengolah data, lembar pengamatan sebagai acuan dalam penelitian, spesies yang diamati (seluruh spesies yang berada diarea penelitian) dan buku identifikasi (Steenis,2006; Wijayakusuma,2001; Tjitrosoepomo, 2007) sebagai pedoman dalam proses identifikasi spesies yang ditemukan.

\section{Metode Penelitian}

Metode yang digunakan adalah deskriptif melalui metode jelajah dan pengambilan spesies. Penelitian dilakukan dengan melakukan observasi di area Wanawiyata Widyakarya, Sanggar Indonesia Hijau. Setiap tumbuhan berkhasiat obat yang ditemukan akan diambil gambarnya sebagai bahan dokumentasi. Pengambilan spesies dengan habitus utuh dilakukan untuk proses identifikasi dengan mengacu pada beberapa literatur. Data yang diperoleh meliputi jenis tanaman obat, nama lokal, nama ilmiah, bagian tanaman yang dimanfaatkan, serta jenis penyakit yang dapat disembuhkan. 


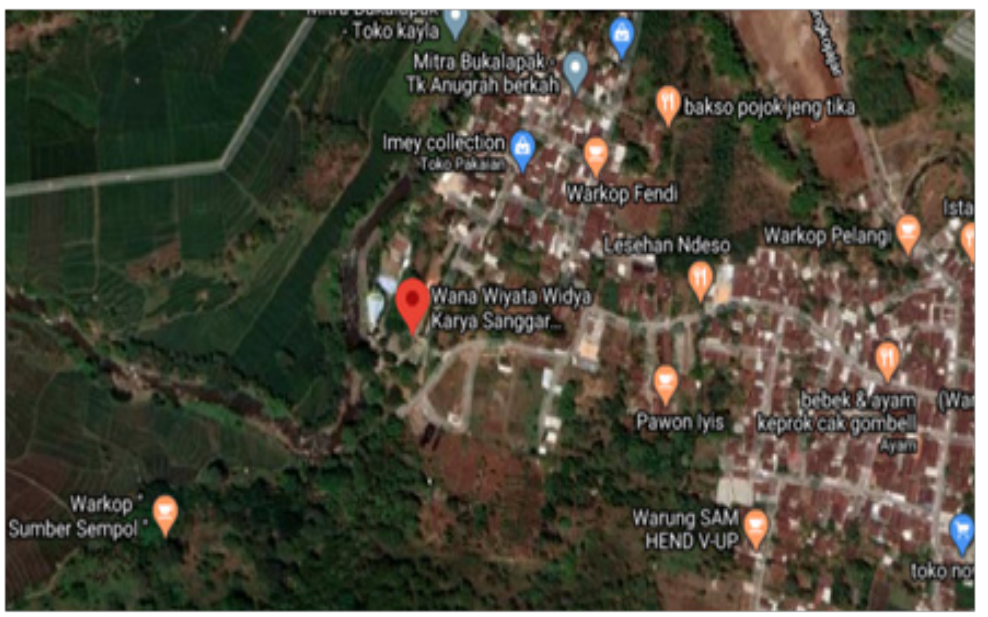

Gambar 1. Peta lokasi penelitian Wana Wiyata Widya Karya Sanggar Indonesia Hijau, Desa Cowek Kecamatan Purwodadi Kabupaten Pasuruan (Google Earth, 2020)

\section{Hasil}

Berdasarkan hasil penelitian yang telah dilakukan di Wana Wiyata Widya Kary, Sanggar Indonesia Hijau, Kabupaten Pasuruan, Provinsi Jawa Timur, berhasil teridentifikasi tanaman berkhasiat obat sejumlah 55 jenis dari 34 famili (Tabel 1).

Hasil identifikasi bagian atau organ tanaman yang dimanfaatkan untuk tujuan pengobatan disajikan dalam Gambar 2.

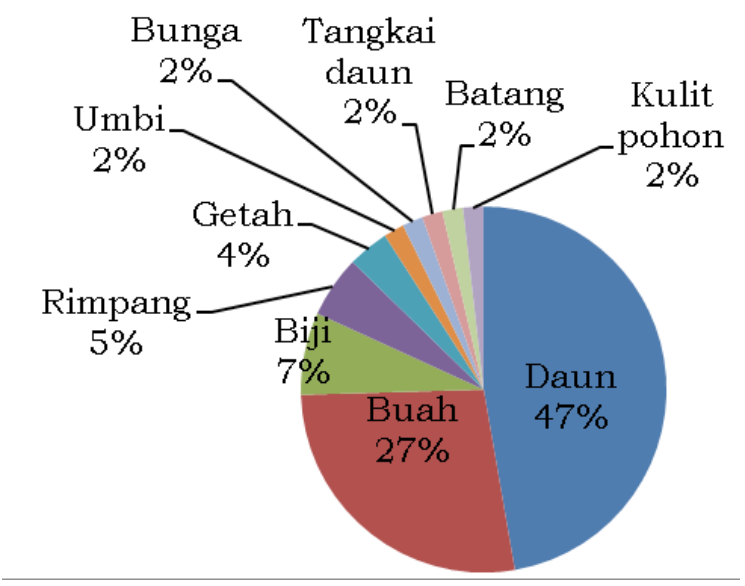

Gambar 2. Organ atau bagian tumbuhan yang dimanfaatkan sebagai obat di Wana Wiyata Widya Karya, Sanggar Indonesia Hijau

Jumlah dan kelompok famili tanaman berkhasiat obat yang diinventarisir dalam penelitian ini disajikan dalam Gambar 3.

\section{Pembahasan}

Jenis tumbuhan berkhasiat obat yang ditemukan di Wana Wiyata Widya Karya, Sanggar Indonesia Hijau ada yang sengaja ditanam dan ada juga yang tumbuh liar. Habitus spesies yang ditemukan di Wana Wiyata Widya Karya, Sanggar Indonesia Hijau antara lain berupa pohon, perdu dan terna.

Pohon merupakan tumbuhan dengan perawakan tinggi besar, batang berkayu dan bercabang jauh dari permukaan tanah. Tinggi pohon dapat mencapai puluhan meter, diameter membesar karena adanya kambium. Contoh spesies dengan habitus pohon yang ditemukan antara lain adalah mangga, asam jawa, dan alpukat. Perdu atau semak merupakan tumbuhan berkayu yang bercabang-cabang mulai dari pangkal batang dengan semua cabang bersifat setara, tumbuh rendah dekat dengan permukaan tanah, dan tidak mempunyai batang yang tegak. Perdu merupakan tumbuhan berkayu yang memiliki struktur lebih kecil daripada pohon, dengan tinggi tanaman kuran dari 6 meter (Tjitrosoepomo, 2007). Contoh perdu yang ditemukan di Wana Wiyata Widya Karya, Sanggar Indonesia Hijau adalah jambu biji, jarak pagar, pucuk merah. Terna atau herba didefinisikan sebagai tumbuhan yang batangnya lunak karena tidak membentuk kayu. Tumbuhan semacam ini dapat merupakan tumbuhan 
Tabel 1. Jenis dan organ tumbuhan yang dimanfaatkan sebagai obat di Wana Wiyata Sanggar Indonesia Hijau

\begin{tabular}{|c|c|c|c|c|}
\hline No & $\begin{array}{l}\text { Nama lokal (nama } \\
\text { ilmiah) }\end{array}$ & $\begin{array}{l}\text { Organ yang } \\
\text { digunakan }\end{array}$ & Familia & Khasiat \\
\hline 1 & $\begin{array}{l}\text { Alpukat } \\
\text { (Persea americana mill) }\end{array}$ & Daun & Lauraceae & $\begin{array}{l}\text { Mengurangi hipertensi, menormalkan sistem } \\
\text { kardiovaskular (Wijayakusuma, 1993) }\end{array}$ \\
\hline 2 & $\begin{array}{l}\text { Asam jawa } \\
\text { (Tamarindus indica) }\end{array}$ & Buah & Fabaceae & $\begin{array}{l}\text { Melancarkan buang air besar, } \\
\text { lancarkan haid (Wijayakusuma, 1993) }\end{array}$ \\
\hline 3 & $\begin{array}{l}\text { Bambu } \\
\text { (Bambusa sp.) }\end{array}$ & Daun & Poaceae & $\begin{array}{l}\text { Meluruhkan dahak, meredakan batuk dan susah } \\
\text { napas (Wijayakusuma, 1993) }\end{array}$ \\
\hline 4 & $\begin{array}{l}\text { Bandotan } \\
\text { (Ageratum conyzoides } \mathrm{L})\end{array}$ & Daun & Asteraceae & $\begin{array}{l}\text { Penyembuh luka luar yang alami (Wijayakusuma, } \\
\text { 1993) }\end{array}$ \\
\hline 5 & $\begin{array}{l}\text { Bawang putih } \\
\text { (Allium sativum L.) }\end{array}$ & Umbi & Liliaceae & $\begin{array}{l}\text { Menurunkan tekanan darah tinggi, mencegah } \\
\text { penyakit jantung dan meningkatkan sistem } \\
\text { kekebalan tubuh (Wijayakusuma, 2001) }\end{array}$ \\
\hline 6 & $\begin{array}{l}\text { Bayam } \\
\text { (Amaranthus spinosus) }\end{array}$ & Daun & Amaranthaceae & $\begin{array}{l}\text { Menanbah darah, memproduksi ASI, mengatasi } \\
\text { gangguan pernafasan dan mengobati demam } \\
\text { (Hariana, 2006) }\end{array}$ \\
\hline 7 & $\begin{array}{l}\text { Belimbing manis } \\
\text { (Averrhoa carambola) }\end{array}$ & Buah & Oxalidaceae & $\begin{array}{l}\text { Mengatasi hipertensi, mencegah kanker, } \\
\text { mengurangi jerawat dan mengurangi kadar } \\
\text { lemak jahat pada darah (Wijayakusuma, 1993) }\end{array}$ \\
\hline 8 & $\begin{array}{l}\text { Bisbul } \\
\text { (Diospyros blancoi) }\end{array}$ & Buah & Ebenaceae & Menjaga sirkulasi darah(Wijayakusuma, 1993) \\
\hline 9 & $\begin{array}{l}\text { Cabai merah } \\
\text { (Capsicum annum L.) }\end{array}$ & Buah & Solanaceae & Menyehatkan jantung (Wijayakusuma, 1993) \\
\hline 10 & $\begin{array}{l}\text { Cabai rawit } \\
\text { (Capsicum frutescens L.) }\end{array}$ & Buah & Solanaceae & Menurunkan berat badan(Wijayakusuma, 1993) \\
\hline 11 & $\begin{array}{l}\text { Durian } \\
\text { (Durio zibhetinus } \\
\text { Murray) }\end{array}$ & Daun & Bombacaceae & Mengobati infeksi (Wijayakusuma, 1993) \\
\hline 12 & $\begin{array}{l}\text { Heliconia } \\
\text { (Heliconia psittacorum) }\end{array}$ & $\begin{array}{l}\text { Tangkai } \\
\text { daun }\end{array}$ & Heliconiaceae & Obat diare (Wijayakusuma, 1993) \\
\hline 13 & $\begin{array}{l}\text { Hanjuang/ andong } \\
\text { (Cordyline fruticosa) }\end{array}$ & Daun & Liliaceae & $\begin{array}{l}\text { Mengobati disentri, wasir, radang gusi, } \\
\text { melancarkan haid, batuk berdarah } \\
\text { (Wijayakusuma, 1993) }\end{array}$ \\
\hline 14 & $\begin{array}{l}\text { Jahe } \\
\text { (Zingiber officinale) }\end{array}$ & Rimpang & Zingiberaceae & $\begin{array}{l}\text { Meredakan mual, turunkan kolesterol, menambah } \\
\text { energi (Wijayakusuma, 2001) }\end{array}$ \\
\hline 15 & $\begin{array}{l}\text { Jamblang } \\
\text { (Syzygium cumini) }\end{array}$ & Kulit pohon & Myrtaceae & Obat Diare (Wijayakusuma, 1993) \\
\hline 16 & $\begin{array}{l}\text { Jambu Biji } \\
\text { (Psidium guajava L.) }\end{array}$ & Daun & Myrtaceae & $\begin{array}{l}\text { Mengobati diare akut dan kronis, perut kembung } \\
\text { pada bayi dan anak, kadar kolesterol darah } \\
\text { meninggi, haid tidak lancar, sering buang air kecil } \\
\text { dan sariawan (Wisaksono, 2008) }\end{array}$ \\
\hline 17 & $\begin{array}{l}\text { Jarak } \\
\text { (Jatropha curcas) }\end{array}$ & Daun & Euphorbiaceae & $\begin{array}{l}\text { Mengobati sakit gigi, memperbaiki kerusakan } \\
\text { hati, gatal-gatal (Tampubolon, 1995) }\end{array}$ \\
\hline 18 & $\begin{array}{l}\text { Jati putih } \\
\text { (Gmelina arborea Roxb) }\end{array}$ & Daun & Verbenaceae & $\begin{array}{l}\text { Membantu mengurangi gejala asma } \\
\text { (Tampubolon, 1995) }\end{array}$ \\
\hline 19 & $\begin{array}{l}\text { Jengger ayam } \\
\text { (Celosia argenta) }\end{array}$ & Bunga & Amaranthaceae & $\begin{array}{l}\text { Anti radang, menghentikan keputihan dan } \\
\text { menerangkan pengelihatan (Wijayakusuma, 1994) }\end{array}$ \\
\hline 20 & $\begin{array}{l}\text { Jeruk manis } \\
\text { (Citrus sinensis) }\end{array}$ & Biji & Rutaceae & Antibakteri (Wijayakusuma, 1993) \\
\hline 21 & $\begin{array}{l}\text { Jeruk purut } \\
\text { (Citrus hystrix) }\end{array}$ & Daun & Rutaceae & $\begin{array}{l}\text { Mengobati influenza, kulit bersisik dan } \\
\text { mengelupas (Dalimarta, 2000) }\end{array}$ \\
\hline 22 & $\begin{array}{l}\text { Kayu putih } \\
\text { (Melaleuca leucadendra) }\end{array}$ & Daun & Myrtaceae & $\begin{array}{l}\text { Meredakan sakit perut, mengatasi insomnia, } \\
\text { demam, flu dan batuk, meredakan sakit gigi, } \\
\text { radang kulit, nyeri tulang dan rematik (Hariana, } \\
\text { 2006) }\end{array}$ \\
\hline 23 & $\begin{array}{l}\text { Kelapa } \\
\text { (Cocos nucifera L.) }\end{array}$ & Buah & Arecaceae & Mengobati demam (Wisaksono, 2008) \\
\hline
\end{tabular}




\begin{tabular}{|c|c|c|c|c|}
\hline No & $\begin{array}{l}\text { Nama lokal (nama } \\
\text { ilmiah) }\end{array}$ & $\begin{array}{l}\text { Organ yang } \\
\text { digunakan }\end{array}$ & Familia & Khasiat \\
\hline 24 & $\begin{array}{l}\text { Keleng } \\
\text { Keng } \\
\text { (Dimocarpus longan) }\end{array}$ & Buah & Sapindaceae & Memperkuat tulang (Wisaksono, 2008) \\
\hline 25 & $\begin{array}{l}\text { Kelor } \\
\text { (Moringa oleifera) }\end{array}$ & Daun & Moringaceae & $\begin{array}{l}\text { Mengobati rematik, nyeri sendi, rabun,membantu } \\
\text { mencegah kanker, asam urat, artritis, Mampu } \\
\text { meningkatkan imunitas (Bose, 2007) }\end{array}$ \\
\hline 26 & $\begin{array}{l}\text { Kenitu } \\
\text { (Chrysophyllum cainito } \\
\text { L.) }\end{array}$ & Daun & Sapotaceae & Mengatasi penyakit diabetes (Wisaksono, 2008) \\
\hline 27 & $\begin{array}{l}\text { Kiara payung } \\
\text { (Filicium decipiens) }\end{array}$ & Daun & Sapindaceae & $\begin{array}{l}\text { Antiseptik membunuh/ mencegah pertumbuhan } \\
\text { mikroorganisme (Wisaksono, 2008) }\end{array}$ \\
\hline 28 & $\begin{array}{l}\text { Kopi } \\
\text { (Coffea sp.) }\end{array}$ & Biji & Rubiaceae & $\begin{array}{l}\text { Mencegah kelebihan kolesterol, penyakit pikun } \\
\text { (Wisaksono, 2008) }\end{array}$ \\
\hline 29 & $\begin{array}{l}\text { Kunyit } \\
\text { (Curcuma domestica) }\end{array}$ & Rimpang & Zingiberaceae & $\begin{array}{l}\text { Mengobati maag/asam lambung (Wisaksono, } \\
\text { 2008) }\end{array}$ \\
\hline 30 & $\begin{array}{l}\text { Lidah Buaya } \\
\text { (Aloe vera) }\end{array}$ & Getah daun & Liliaceae & Mengobati luka luar (Wisaksono, 2008) \\
\hline 31 & $\begin{array}{l}\text { Loa } \\
\text { (Ficus racemosa) }\end{array}$ & Buah & Moraceae & $\begin{array}{l}\text { Mengobati diabetes, rematik, asma, bronkitis, } \\
\text { batuk kering (Wisaksono, 2008) }\end{array}$ \\
\hline 32 & $\begin{array}{l}\text { Mahoni } \\
\text { (Swietenia mahagoni) }\end{array}$ & Biji & Meliaceae & Menurunkan gula darah (Wisaksono, 2008) \\
\hline 33 & $\begin{array}{l}\text { Mangga } \\
\text { (Mangifera indica) }\end{array}$ & Buah & Anacardiaceae & Mengendalikan diabetes (Wisaksono, 2008) \\
\hline 34 & $\begin{array}{l}\text { Matoa } \\
\text { (Pometia pinnata) }\end{array}$ & Buah & Sapindaceae & $\begin{array}{l}\text { Menekan pertumbuhan infeksi virus berbahaya, } \\
\text { mengatasi stres, meningkatkan kesuburan pria } \\
\text { dan wanita, menangkal radikal bebas, menjaga } \\
\text { kesehatan kulit (Wisaksono, 2008) }\end{array}$ \\
\hline 35 & $\begin{array}{l}\text { Meniran } \\
\text { (Phyllanthus niruri) }\end{array}$ & Daun & Euphorbiaceae & $\begin{array}{l}\text { Obat penyakit kuning, kencing nanah } \\
\text { (gonorrhoea), gangguan pencernaan, diabetes } \\
\text { luka pada kulit,diare (Wisaksono, 2008) }\end{array}$ \\
\hline 36 & $\begin{array}{l}\text { Mentimun } \\
\text { (Cucumis satious L.) }\end{array}$ & Buah & Cucurbitaceae & ObatHipertensi (Wisaksono, 2008) \\
\hline 37 & $\begin{array}{l}\text { Nangka } \\
\text { (Artocarpus } \\
\text { heterophyllus) }\end{array}$ & Daun & Moraceae & Penyembuh luka, bisul (Aspan et al, 2008) \\
\hline 38 & $\begin{array}{l}\text { Pepaya } \\
\text { (Carica papaya) }\end{array}$ & Daun & Caricaceae & Mengobati malaria (Wijayakusuma, 2001) \\
\hline 39 & $\begin{array}{l}\text { Petai } \\
\text { (Parkia speciosa) }\end{array}$ & Buah & Mimosaceae & $\begin{array}{l}\text { Obat anemia, depresi,stres, sakit perut, cacingan, } \\
\text { asam urat (Wijayakusuma, 2001) }\end{array}$ \\
\hline 40 & $\begin{array}{l}\text { Pinus } \\
\text { (Pinus merkusii Jungh. } \\
\text { et de Vriese) }\end{array}$ & Getah & Pinaceae & Sebagai obat luka (Wijayakusuma, 2001) \\
\hline 41 & $\begin{array}{l}\text { Pisang } \\
\text { (Musa paradisiaca) }\end{array}$ & Batang & Musaceae & $\begin{array}{l}\text { Menyembuhkan asam lambung (Aspan et al, } \\
\text { 2008) }\end{array}$ \\
\hline 42 & $\begin{array}{l}\text { Pucuk merah } \\
\text { (Syzygium oleana) }\end{array}$ & Daun & Myrtaceae & $\begin{array}{l}\text { Sebagai antioksidan alami, obat diabetes } \\
\text { (Wijayakusuma, 2001) }\end{array}$ \\
\hline 43 & $\begin{array}{l}\text { Puring } \\
\text { (Codiaeum variegatum) }\end{array}$ & Daun & Euphorbiaceae & $\begin{array}{l}\text { Obat antifungal, antikanker, obat diare dan obat } \\
\text { penahan rasa sakit (Wijayakusuma, 2001) }\end{array}$ \\
\hline 44 & $\begin{array}{l}\text { Rambutan } \\
\text { (Nephelium lappaceum } \\
\text { L.) }\end{array}$ & Daun & Sapindaceae & Diabetes (Aspan et al, 2008) \\
\hline 45 & $\begin{array}{l}\text { Salam } \\
\text { (Syzygium polyanthum) }\end{array}$ & Daun & Myrtaceae & Menurunkan asam urat (Wijayakusuma, 2001) \\
\hline 46 & $\begin{array}{l}\text { Sawo manila } \\
\text { (Manilkara zapota }(\underline{\mathrm{L}} .) \mathrm{P} . \\
\text { Royen) }\end{array}$ & Daun & Sapotaceae & $\begin{array}{l}\text { Obat penyakit kulit, misal jerawat (Aspan et al, } \\
\text { 2008) }\end{array}$ \\
\hline 47 & $\begin{array}{l}\text { Sengon buto } \\
\text { (Enterolobium } \\
\text { cyclocarpum) }\end{array}$ & Biji & Fabaceae & $\begin{array}{l}\text { Menurunkan tekanan darah tinggi, kolesterol, } \\
\text { asam urat (Wijayakusuma, 2001) }\end{array}$ \\
\hline
\end{tabular}




\begin{tabular}{|c|c|c|c|c|}
\hline No & $\begin{array}{l}\text { Nama lokal (nama } \\
\text { ilmiah) }\end{array}$ & $\begin{array}{l}\text { Organ yang } \\
\text { digunakan }\end{array}$ & Familia & Khasiat \\
\hline 48 & $\begin{array}{l}\text { Serai } \\
\text { (Cymbopogon citratus) }\end{array}$ & Rimpang & Poaceae & $\begin{array}{l}\text { Mengobati nyeri pinggang, masuk angin, sakit } \\
\text { kepala,sakit perut (Wijayakusuma, 2001) }\end{array}$ \\
\hline 49 & $\begin{array}{l}\text { Singkong } \\
\text { (Manihot utilissima) }\end{array}$ & Daun & Euphorbiaceae & Menambah imunitas tubuh (Wijayakusuma, 2001) \\
\hline 50 & $\begin{array}{l}\text { Sirih hijau } \\
\text { (Piper betle) }\end{array}$ & Daun & Piperaceae & Mengobati luka (Wijayakusuma, 2001) \\
\hline 51 & $\begin{array}{l}\text { Sirih merah } \\
\text { (Piper crocatum) }\end{array}$ & Daun & Piperaceae & Menurunkan gula darah (Wijayakusuma, 2001) \\
\hline 52 & $\begin{array}{l}\text { Sirsak } \\
\text { (Annona muricata) }\end{array}$ & Buah & Annonaceae & Malaria, tipes, nyeri sendi (Aspan, 2008) \\
\hline 53 & $\begin{array}{l}\text { Stroberi } \\
\text { (Fragaria virginiana) }\end{array}$ & Buah & Rosaceae & $\begin{array}{l}\text { Mengurangi peradangan pada sendi (Aspan et al, } \\
\text { 2008) }\end{array}$ \\
\hline 54 & $\begin{array}{l}\text { Sukun } \\
\text { (Artocarpus altilis) }\end{array}$ & Daun & Moraceae & Menurunkan gula darah (Wijayakusuma, 2001) \\
\hline 55 & $\begin{array}{l}\text { Tomat } \\
\text { (Solanum lycopersicum) }\end{array}$ & Buah & Solanaceae & Sumber vitamin, masker wajah (Aspan et al, 2008) \\
\hline
\end{tabular}

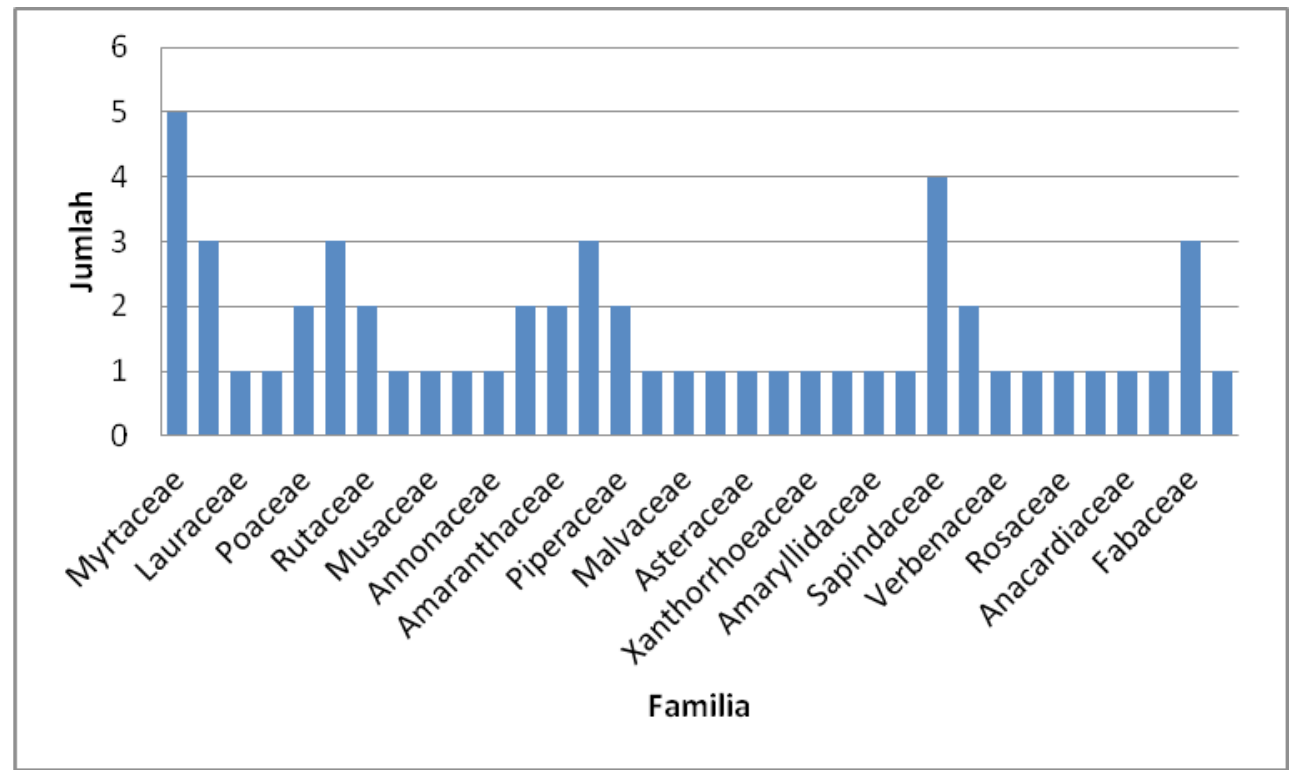

Gambar 3. Kelompok famili tumbuhan berkhasiat obat di Wana Wiyata Widya Karya, Sanggar Indonesia Hijau

semusim, tumbuhan dwimusim, ataupun tumbuhan tahunan. Terna atau herba merupakan tumbuhan dengan habitus pendek dan kecil yang mempunyai batang basah karena mengandung banyak air (Tjitrosoepomo, 2007). Contoh herba yang ditemukan di Wana Wiyata Widya Karya, Sanggar Indonesia Hijau adalah bandotan, jahe, jengger ayam, dan sirih hijau.

Tabel 1 menuliskan 55 spesies tumbuhan berkhasiat obat yang teridentifikasi tumbuh di Wana Wiyata Widya Karya, Sanggar Indonesia Hijau. Pemanfaatan tanaman berkhasiat obat ini dilakukan dengan pengolahan organ atau bagian tanaman tersebut seperti buah, biji, daun dan sebagainya. Hasil identifikasi organ atau bagian tanaman yang bisa dimanfaatkan untuk tujuan pengobatan menghasilkan 10 bagian atau organ yaitu daun, buah, biji, rimpang, getah, kulit pohon, umbi, bunga, tangkai daun dan batang (Gambar 3). Organ atau bagian tanaman yang dimanfaatkan untuk tujuan pengobatan berbeda-beda untuk setiap spesies. Beberapa contoh pemanfaatan organ atau bagian tanaman 
yang diidentifikasi dari Wana Wiyata Widya Karya, Sanggar Indonesia Hijau selain bisa disajikan dalam Tabel 1 juga bisa dituliskan sebagian sebagai berikut : seduhan organ daun Alpukat (Persea americana) berpotensi mengurangi hipertensi dan menormalkan sistem kardio vaskular (Wijayakusuma, 1993), organ buah belimbing manis (Averrhoa carambola) bermanfaat untuk mengatasi hipertensi, mencegah kanker, mengurangi jerawat dan mengurangi kadar lemak jahat pada darah (Wijayakusuma, 1993), batang pisang (Musa paradisiaca) dapat dimanfaatkan sebagai obat alternatif gangguan asam lambung (Aspan et al, 2008) dan organ umbi bawang putih (Allium sativum) bisa berguna untuk menurunkan tekanan darah tinggi, mencegah penyakit jantung dan meningkatkan sistem kekebalan tubuh. (Wijayakusuma, 2001). Penggunaan bahan pengobatan berbasis tanaman ini bermanfaat bagi manusia karena sifatnya yang alamiah dan murah.

Hasil penelitian ini menunjukkan persentase pemanfaatan organ atau bagian tanaman berkhasiat obat terinci sebagai berikut : daun $(47 \%)$, buah (27\%), biji $(7 \%)$, rimpang $(5 \%)$, getah $(4 \%)$, dan masing-masing kulit pohon, umbi, bunga, tangkai daun dan batang sebanyak $2 \%$. Daun merupakan organ tumbuhan yang paling banyak dimanfaatkan untuk tujuan pengobatan karena cara memperolehnya lebih mudah jika dibanding dengan cara memperoleh organ tumbuhan yang lain. Contoh yang bisa diambil adalah bunga dan buah. Oleh karena tidak setiap saat bunga dan buah tanaman terbentuk, maka cara memperolehnya lebih sulit dibandingkan dengan cara memperoleh daun tumbuhan tersebut.

Hasil penelitian menunjukkan bahwa 55 spesies tanaman berkhasiat obat yang teridentifikasi di Wana Wiyata Widya Karya, Sanggar Indonesia Hijau tergolong dalam 34 famili (Gambar 3). Tiga puluh empat famili tanaman berkhasiat obat beserta jumlah spesies tanaman anggotanya adalah Myrtaceae (5 spesies), Euphorbiaceae (3 spesies), Lauraceae (1 spesies), Caricaceae (1 spesies), Poaceae (2 spesies), Moraceae (3 spesies), Rutaceae (2 spesies), Moringaceae (1 spesies), Musaceae (1 spesies), Rubiaceae (1 spesies), Annonaceae (1 spesies), Zingiberaceae (2 spesies), Amaranthaceae (2 spesies), Solanaceae ( 3 spesies), Piperaceae (2 spesies), Arecaceaen (1 spesies), Malvaceae (1 spesies), Oxalidaceae (1 spesies), Asteraceae (1 spesies), Phyllanthaceae (1 spesies), Xanthorrhoeaceae (1 spesies), Amaryllidaceae (1 spesies), Cucurbitaceae (1 spesies), Sapindaceae (4 spesies), Sapotaceae (2 spesies), Verbenaceae (1 spesies), Pinaceae (1 spesies), Rosaceae (1 spesies), Ebenaceae (1 spesies), Anacardiaceae (1 spesies), Meliaceae (1 spesies), Fabaceae (3 spesies), Heliconiaceae (1 spesies) dan Asparagaceae (1 spesies).

Jumlah famili yang paling banyak ditemukan di lokasi penelitian adalah Myrtaceae dengan jumlah 5 spesies yang terdiri dari : jamblang (Syzygium cumini), jambu biji (Psidium guajava), kayu putih (Melaleuca leucadendra), pucuk merah (Syzygium oleana) dan salam (Syzygium polyanthum).

Identifikasi dan inventarisasi spesies dan famili tanaman berkhasiat obat di Wana Wiyata Widya Karya, Sanggar Indonesia Hijau, Kabupaten Pasuruan bisa digunakan sebagai gambaran data koleksi dan potensi tanaman setempat untuk dapat dikembangkan pelestarian dan pemanfaatannya sebagai tanaman obat yang dibutuhkan untuk menunjang kualitas kesehatan masyarakat sehari-hari.

\section{Kesimpulan}

Inventarisasi tumbuhan obat di Wana Wiyata Widya Karya, Sanggar Indonesia Hijau, Kabupaten Pasuruan menunjukkan terdapatnya 55 jenis tumbuhan obat dari 34 familia. Terdapat 10 jenis organ atau bagian tumbuhan yang dapat dimanfaatkan sebagai obat dengan presentase organ atau bagian tumbuhan obat yang paling banyak digunakan adalah daun sebesar $47 \%$, buah sebesar $27 \%$, biji sebesar $7 \%$, rimpang sebesar $5 \%$, getah sebesar $4 \%$, dan masing-masing kulit pohon, umbi, bunga, tangkai daun dan batang sebanyak $2 \%$. 


\section{Daftar Pustaka}

Aspan, R., Sherley, Napitupulu, R, Wisaksono, L.S., Efrizal., Mooduto,L., Herawaty, T.,Novianti, A., Wahyu, S. \& Tumino (2008).Taksonomi Koleksi Tumbuhan Obat Kebun Tumbuhan Obat. Bidang Biologi LIPI. Citeureup.

Agoez, A. (2010). Tanaman Obat Indonesia. Jakarta: Salemba Medika

Bose, C.K., (2007). Possible role of Moringa Oleifera L. root in epithelial ovarian cancer. Medscape General Medicine, 9(1): 26.

Hariana, A. (2006). Tumbuhan Obat dan Khasiatnya. Seri 2. Jakarta: Penebar Swadaya.

Heyne, K. (1987). Tumbuhan Berguna Indonesia, Jilid 1. Departemen Kehutanan, Jakarta.

Pranata, S. T. (2014). Herbal Toga Tanaman Obat keluarga, Yogyakarta: Aksara Sukses.

Steenis, C., G., J., V. (2006). Flora Pegunungan Jawa. Jakarta: PT. Pradnya Paramita

Tampubolon, O.T. (1995). Tumbuhan Obat. Bhatara Press. Jakarta.

Tjitrosoepomo, G. (1998). Taksonomi Umum, Yogyakarta: Gadjah Mada University Press.

Tjitrosoepomo, G. (2007). Taksonomi Tumbuhan (Spermatophyta). Gadjah Mada University Press Yogyakarta

Wijayakusuma, H. Wirian, S.A. Yaputra, T.Dalimartha, S., \& Wibowo, B. (1993). Tanaman Berkhasiat Obat di Indonesia Jilid II. Pustaka Kartini. Jakarta.

Wijayakusuma, H. (2001). Tumbuhan Berkhasiat Obat: Rempah, Rimpang, dan Umbi. Milenia Popular. Jakarta.

Wisaksono, L.S., Napitupulu, R., Efizal., Mooduto, L., Herawaty, T., Novianti,A., Wahyu, S., \& Tumino. (2008). Taksonomi Koleksi Tanaman Obat Kebun Tanaman Obat Citeureup. 